\title{
FAKTOR- FAKTOR YANG BERHUBUNGAN DENGAN TERJADINYA KATARAK SENILIS PADA PASIEN DI POLI MATA RSUD BANGKINANG
}

\author{
M.Nizar Syarif Hamidi, Ahmad Royadi \\ Dosen dan Alumni FIK Universitas Pahlawan Tuanku Tambusai, Riau, Indonesia \\ nizar_hamidi@yahoo.com
}

\begin{abstract}
ABSTRAK
World Hearth Organization (WHO), sedikitnya terdapat 135 juta orang yang mengalami disabilitas penglihatan yang sangat signifikan dan terdapat lebih dari 50 juta orang buta di seluruh dunia saat ini, dengan penyebab kebutaan terbanyak adalah katarak (51\%).Terjadinya katarak senilisberhubungan dengan diabetes melitus, riwayat keluarga dengan katarak, pemakaian steroid yang lama, merokok, terpajan sinar ultravioet (UV). Tujuan penelitian ini adalah untuk mengetahui faktor- faktor yang berhubungan dengan terjadinya katarak senilis pada pasien di poli mata RSUD Bangkinang. Desain penelitian ini adalah analitik deskriptif dengan rancangan penelitian cross sectional. Sampel dalam penelitian ini adalah 30 orang penderita katarak di poli mata RSUD Bangkinang yang dilaksanakan 11-23 Juli 2016, dengan menggunakan teknik Accidental Sampling. Data yang digunakan dalam penelitian ini adalah data primer dan data sekunder. Analisa yang digunakan adalah univariat dan bivariat. Hasil penelitian uji statistik menggunakan uji Chi Square pada tingkat kemaknaan 95\% ( $\leq 0,05)$, menunjukkan bahwayang mengalami katarak senilis sebanyak 22 orang $(73,3 \%)$, diabetes melitus 20 orang $(66,7 \%)$, riwayat keluarga dengan katarak sebanyak 17 orang $(56,7 \%)$, tidak memakai obat steroid yang lama sebanyak 19 orang $(63,3 \%)$, merokok sebanyak 21 orang $(70,0 \%)$, terpajan sinar ultraviolet sebanyak 23 orang $(76,7 \%)$. Didapatkan ada hubungan riwayat diabetes melitus ( $p$ value 0,007$)$, riwayat keluarga dengan katarak ( $p$ value $0,009)$, merokok ( $p$ value 0,03 ), terpajan sinar ultraviolet (matahari) ( $p$ value 0,00$)$ dengan kejadian katarak senilis, tidak ada hubungan pemakaian steroid lama ( $p$ value 0,67$)$ dengan kejadian katarak senilis. Diharapkan kepada responden untuk menggunakan pelindung mata (kaca mata buram), menghindari merokok dan mengontrol kadar gula darah secara rutin.
\end{abstract}

Daftar Bacaan : $28(2004-2015)$

Kata Kunci :Riwayat Diabetes Melitus, Riwayat Keluarga dengan Katarak, Pemakaian Steroid yang lama, Merokok, Terpajan Sinar Ultraviolet, Katarak 


\section{PENDAHULUAN}

\section{A. Latar Belakang}

Mata adalah salah satu indera yang penting bagi manusia, melalui mata manusia menyerap informasi visual yang digunakan untuk melaksanakan berbagai kegiatan. Namun gangguan terhadap penglihatan banyak terjadi, mulai dari gangguan ringan hingga gangguan yang berat yang dapat mengakibatkan

kebutaan. Kebutaan karena katarak atau kekeruhan lensa mata merupakan masalah kesehatan global yang harus segera diatasi, karena kebutaan dapat menyebabkan berkurangnya kualitas sumber daya manusia dan kehilangan produktifitas serta membutuhkan biaya yang cukup besar untuk pengobatannya. Katarak dapat terjadi pada semua umur (Ilyas, 2014).

Katarak merupakan penyebab sedikitnya $50 \%$ kasus kebutaan di seluruh dunia. Seiring dengan peningkatan usia harapan hidup, jumlah orang yang terkena semakin bertambah. Di berbagai bagian dunia yang sedang berkembang, fasilitas yang bersedia untuk mengobati katarak jauh dari mencukupi, sulit untuk mengatasi kasuskasus baru yang muncul dan benar-benar tidak mampu menangani kasus-kasus lama semakin menumpuk, yang dalam hitungan konservatif diperkirakan berjumlah 10 juta diseluruh dunia.

\section{World Hearth Organization} (WHO, 2013), memperkirakan bahwa penyebab gangguan penglihatan terbanyak di seluruh dunia adalah gangguan refraksi yang tidak terkoreksi, diikuti oleh katarak dan glaukoma. Sedikitnya terdapat 135 juta orang yang mengalami disabilitas penglihatan yang sangat signifikan dan terdapat lebih dari 50 juta orang buta di seluruh dunia saat ini, dengan penyebab kebutaan terbanyak adalah katarak (51\%), diikuti oleh glaukoma dan Age related Macular Degeneration (AMD). Sebesar 21\% tidak dapat ditentukan penyebabnya dan
4\% adalah gangguan penglihatan sejak masa kanak-kanak.

Pemerintah Republik indonesia melalui Kementerian Kesehatan RI, sejak tahun 2000 bersama-sama WHO telah mencanangkan Visi 2020 yaitu, The Right to Sight. Dalam visi 2020 the right to sight merupakan program yang diinisiasi oleh WHO dan international agensi for the prefention of blindess (LAPB) untuk mewujudkan fungsi penglihatan yang optimal di dunia. Indonesia sebagai Negara dengan angka kebutaan ketiga terbanyak didunia turut berkomitmen dalam upaya pemberantasan kebutaan. (PERDAMI, 2013).

Indonesia sebagai Negara berkembang banyak mengalami masalah kesehatan mata. Perkiraan insiden katarak adalah $0,1 \%$ pertahun atau setiap tahun di antara 1.000 orang terdapat seorang penderita baru katarak. Penduduk Indonesia juga memiliki kecenderungan menderita katarak 15 tahun lebih cepat dibandingkan penduduk di daerah subtropis, sekitar 16 - 22\% penderita katarak yang dioperasi berusia di bawah 55 tahun. Prevalensi katarak di Indonesia menurut hasil pemeriksaan petugas enumerator dalam Riskesdas 2013 adalah sebesar 1,8\%, tertinggi di Provinsi Sulawesi Utara $(3,7 \%)$ dan terendah di DKI Jakarta (0,9\%). (Depkes RI, 2013).

Sedangkan prevalensi katarak di propinsi Riau sebesar 1,9 persen, prevalensi tertinggi terlihat di Indragiri Hilir $(3,1 \%)$ diikuti oleh Pelalawan $(3,0 \%)$ dan Kuantan Singingi $(2,7 \%)$. Prevalensi katarak terendah ditemukan di Indragiri Hulu (0,9\%) diikuti Rokan Hulu dan Rokan Hilir (masing-masing $1,1 \%$ ). Sedangkan prevalensi katarak di Kabupaten Kampar adalah 1,2\%. (Riskesdas, 2013).

RSUD Bangkinang merupakan salah satu Rumah Sakit tipe C yang ada di Kabupaten Kampar. Salah satu pelayanannya adalah pemeriksaan dan 
pengobatan penderita katarak, baik yang datang sendiri maupun rujukan dari Puskesmas.

Adapun data pasien berdasarkan kunjungan rawat jalan di poli mata RSUD Bangkinang selama Januari sampai dengan Desember 2015 sebanyak 5.509 kunjungan, sebagian besar adalah penderita katarak senil (berumur 50 - 85 tahun), yaitu sebanyak857penderita,dengankasus lama sebanyak 416 kunjungan dan kasusbarusebanyak441 penderita.

Sesuai dengan perkembangan usia, lensa kristalin bersifat jernih selama masa pertumbuhan hingga usia kurang lebih 45 tahun, setelah itu mulai terjadi progresifitas kekeruhan pada lensa kristalin oleh karena kerusakan protein dan sel lensa. Secara umum, penyebab katarak dapat dibagi menjadi kongenital dan didapat. Sebagian katarak yang ditemukan adalah yang didapat, dengan sebagian besar berhubungan dengan penuaan. (Budiman, 2013).

Katarak bisa dialami pada semua umur bergantung pada faktor pencetusnya. Beberapa faktor yang diduga dapat mempengaruhi kejadian penyakit katarak senilis seperti penuaan, radang mata, trauma mata, diabetes melitus, riwayat keluarga dengan katarak, pemakaian steroid lama (oral) atau tertentu lainnya, pembedahan mata, merokok, terpajan banyak sinar ultra violet (matahari). (Ilyas, 2014).

Dengan mengetahui faktor-faktor yang mempangruhi penyakit katarak diharapkan dapat meningkatkan pencegahan dalam penurunan jumlah penderita penyakit katarak.

Diabetes melitus merupakan kelainan metabolik yang ditandai dengan hiperglikemia yang terkait dengan sekresi insulin, defek aksi insulin atau keduanya. Kondisi hiperglikemia kronik ini berhubungan dengan sekuele jangka panjang yang signifikan, yaitu kerusakan, disfungsi dan kegagalan pada beberapa organ, khususnya ginjal, mata, saraf, jantung dan pembuluh darah. Pada mata dapat menyebabkan edema lensa akibat sorbitol (alkohol gula). (Budiman, dkk, 2013).

Riwayat keluarga dengan katarak dapat berpengaruh terhadap penerusan gen kepada keturunan. Beberapa gen kristalin diekspresikan pada awal embriogenesis, dan mutasi pada gen ini dapat menyebabkan perubahan pada protein yang berperan terhadap agregasi protein hingga mengakibatkan terjadinya katarak. (Budiman, 2013).

Penggunaan jangka panjang (lebih dari 40 hari) steroid atau dosis tinggi steroid dapat menyebabkan dua masalah mata yaitu katarak dan glaukoma. Jenis katarak yang bisa terjadi yaitu katarak kortikal posterior. Biasanya pada penggunaan kortikosteroid dalam jangka waktu yang lama bisa menyebabkan katarak posterior sub kapsular. Patofisiologi terjadinya katarak akibat pemberian kortikosteroid dalam jangka waktu lama belum bisa dipastikan dengan jelas. Namun yang pasti jenis kortikosteroid yang bisa menyebabkan terjadinya katarak yaitu jenis glukokortikoid (hidrokortison, deksametason, metilprednisolon). Ini semua berhubungan dengan metabolisme karbohidrat, lemak, dan protein, dan berhubungan dengan anti inflamasi dengan cara menghambat pelepasan fosfolipid.Secara teori, kortikosteroid menginduksi protein (miosilin) yang berada di daerah trabekulum sehingga menyebabkan terjadinya edema di daerah tersebut. Edema tersebut yang menginduksi terjadinya glaukoma sudut terbuka. (http://mata-fkuirscm.org/penggunaan-kortikosteroid/).

Terpajan banyak sinar ultra violet (matahari), dapat memberikan kerusakan terbatas pada kornea hingga kerusakan pada lensa dan retina, sifatnya dapat merusak epitel pada bagian-bagian mata. (Ilyas, 2014).

Pekerjaan dalam hubungannya dengan paparan sinar matahari, sinar 
ultraviolet, yang berasal dari sinar matahari (lebih dari 4 jam) akan diserap oleh protein lensa terutama asam amino aromatik, yaitu triptofan, fenil alanin dan tirosin dan kemudian akan menimbulkan reaksi fotokimia sehingga terbentuk radikal bebas atau spesies oksigen yang bersifat sangat reaktif. Reaksi oksidatif ini akan mengganggu struktur protein pada lensa sehingga terjadi cross link antar dan intra protein dan menambah jumlah high molecular weight protein yang menyebabkan agregasi protein, kemudian akan menimbulkan kekeruhan lensa atau yang disebut katarak. (Amanda, 2015).

Merokok merupakan faktor risiko yang terkenal untuk berbagaimacam penyakit. Sekarang, para ilmuwan memiliki bukti bahwa merokok juga dapat meningkatkan risiko katarak yang berkaitan dengan usia, penyebab utama kebutaan dan kehilangan penglihatan. Hasil penelitian menunjukkan bahwa setiap individu yang pernah merokok dikaitkan dengan peningkatan risiko katarak terkait usia, dengan risiko yang lebih tinggi dari kejadian pada perokok. Dalam analisis subkelompok, mantan dan saat ini perokok menunjukkan hubungan positif dengan dua subtipe: katarak nuklir, ketika kekeruhan adalah di inti pusat mata, dan katarak subskapularis, ketika kekeruhan adalah di belakang kapsul lensa. Sedangkan analisis secara keseluruhan menunjukkan bahwa semakin bertambahnya usia, merokok dapat meningkatkan risiko katarak. (http://www.news-

medical.net/news/20121013/).

Menurut Amanda seseorang yang merokok 10 batang atau lebih per harinya mempunyai risiko 2 kali lebih banyak mengalami katarak. Setelah dilakukan studi pendahuluan oleh peneliti di Poliklinik Mata RSUD Bangkinang, didapatkan hasil wawancara bahwa Tn. S yang datang berkunjung untuk berobat ke
Poliklinik Mata RSUD Bangkinang sebelumnya memiliki riwayat penyakit DM, dan telah memiliki umur Lanjut Usia (Lansia), dan Ny. $\mathrm{H}$ salah satu penderita katarak di poli mata mengatakan bahwa 2 tahun dirinya telah memiliki riwayat penyakit DM dan bekerja diluar gedung dalam arti terpapar oleh sinar matahari dalam jangka waktu yang lama.

Berdasarkan permasalahan diatas masih tingginya prevalensi katarak di RSUD Bangkinang dan belum diketahuinya faktor-faktor yang mempengaruhi kejadian katarak senilis terhadap pasien yang berkunjung di poli mata RSUD Bangkinang, maka peneliti merasa penting untuk melakukan penelitian tentang "Faktor-faktor yang berhubungan dengan terjadinya katarak senilis pada pasien di poli mata RSUD Bangkinang"

\section{B. Rumusan Masalah}

Berdasarkan latar belakang diatas maka rumusan masalah penelitian ini yaitu:"Faktor-faktor apakah yang berhubungan dengan terjadinya katarak senilis pada pasien di poli mata RSUD Bangkinang? ".

\section{TujuanPenelitian}

1. TujuanUmum

Berdasarkan rumusan masalah diatas, tujuan umum pada penelitian ini adalah untuk mengetahuifaktorfaktor yang berhubungan dengan terjadinya katarak senilis pada pasien di poli mata RSUD Bangkinang.

2. TujuanKhusus

Tujuan khusus penelitian ini adalah:

a. Mengetahui distribusi frequensi katarak senilispada pasien di poli mata RSUD Bangkinang.

b. Mengetahui distribusi frequensi diabetes melituspada pasien katarak senilis dipoli mata RSUD Bangkinang.

c. Mengetahui distribusi frequensi riwayat keluarga dengan katarak pada pasien 
kataraksenilis di poli mata RSUD Bangkinang.

d. Mengetahui distribusi frequensi pemakaian steroid lama pada pasien katarak senilis di poli mata RSUD Bangkinang.

e. Mengetahui distribusi frequensi merokok pada pasien katarak senilis di poli mata RSUD Bangkinang.

f. Mengetahui distribusi frequensi terpajan banyak sinar ultra violet (matahari) pada pasien katarak senilis di poli mata RSUD Bangkinang.

g. Untuk mengetahui hubungan faktordiabetes melitus terhadap terjadinya katarak senilis pada pasien di poli mata RSUD Bangkinang.

h. Untuk mengetahui hubungan faktor riwayat keluarga dengan katarak terhadap terjadinya katarak senilis pada pasien di poli mata RSUD Bangkinang.

i. Untuk mengetahui hubunganfaktorpemakaian steroid lama (oral) terhadap terjadinya katarak senilis pada pasien di poli mata RSUD Bangkinang.

j. Untuk mengetahui hubungan faktormerokok terhadap terjadinya katarak senilis pada pasien di poli mata RSUD Bangkinang.

k. Untuk mengetahui hubungan faktorterpajan banyak sinar ultra violet (matahari)terhadap

\section{METODE PENELITIAN}

A. Desain Penelitian

Pada penelitian ini penulis menggunakan metode analitik deskriptif dengan rancangan penelitian cross sectional yaitu rencana penelitian dengan melakukan pengukuran atau pengamatan pada saat bersamaan (sekali waktu) dengan maksud untuk mengetahui hubungan dengan varibel (Hidayat, 2007). terjadinya katarak senilis pada pasien di poli mata RSUD Bangkinang.

\section{ManfaatPenelitian}

1. Manfaat teoritis

Hasil penelitian ini dapat bermanfaat untuk mengetahui berbagai faktor risiko sebagai penyebab terjadinya katarak senilis pada pasien di Poli Mata RSUD Bangkinang, serta dapat dijadikan sebagai dasar untuk penelitian selanjutnya.

2. Manfaat praktis

Bagi peneliti;

Penelitian ini diharapkan dapat menambah pengalaman dan wawasan peneliti serta menjadi media untuk menerapkan ilmu khususnya faktor risiko sebagai penyebab terjadinya katarak senilis.

Bagi tenaga kesehatan;

Sebagai bahan masukan untuk membuat program kesehatan, sebagai bahan penyuluhan, sebagai promosi kesehatan yang disampaikan oleh tenaga kesehatan kepada masyarakat luas mengenai berbagai faktor risiko katarak senilis.

Bagi masyarakat;

Hasil penelitian ini diharapkan dapat meningkatkan kesadaran masyarakat tentang penggunaan alat pelindung diri pada saat bekerja di luar gedung, dan menjadi sumber pengetahuan masyarakat tentang pengaruh berbagai faktor risiko terhadap katarak senilis.

Dimana data-data yang berkaitan dengan variabel independen maupun dependen dikumpulkan secara bersamaan untuk mendapatkan informasi tentang faktor-faktor yang berhubungan dengan kejadian katarak senilis pada pasien yang berkunjung ke poli mata RSUD Bangkinang tahun 2016 dengan menggunakan pertanyaan kuesioner.

B. Lokasi dan Waktu Penelitian

1. Lokasi penelitian 
Penelitian ini dilaksanakan di Poli Mata RSUD Bangkinang. Alasan tempat penelitian disini karena RSUD Bangkinang merupakan satusatunya Rumah Sakit rujukan pasien mata di Kabupaten Kampar.

2. Waktu penelitian

Penelitian ini dilaksanakan selama 2 minggu yang dilakukan pada bulan Juli 2016.

\section{Populasi dan Sampel}

1. Populasi

Populasi ini mencakup semua pasien dengan diagnosis medis katrak yang berkunjung ke Poli Mata RSUD Bangkinang saat penelitian dilakukan.

\section{Sampel}

Sampel dalam penelitian ini adalah seluruh penderita katarak yang datang berobat pada saat penelitian yang sesuai dengan kriteria sampel yang telah ditetapkan.

Jumlah sampel yang direncanakan dalam penelitian ini adalah sampel minimal sebanyak 30 orang penderita katarak.

a. Kriteria sampel

Untuk mendapatkan jawaban yang dibutuhkan maka peneliti menetapkan beberapa kriteria sampel, yaitu:

1) Kriteria Inklusi

a) Pasien yang berkunjung ke poli mata RSUD Bangkinang yang menderita katarak.

b) Usia responden $>45$ tahun.

c) Data rekam medis responden lengkap tentang diagnosa katarak dan diabetes melitus beserta hasil laboratorium.

\section{2) Kriteria Eksklusi}

Penderita yang mengalami katarak yang tidak bersedia untuk di wawancara.

\section{b. Teknik Sampling}

Teknik yang digunakan dalam pengambilan sampel pada penelitian ini adalah Accidental

Sampling yaitu merupakan pengambilan sampel yang ditemukan pada saat penelitian dilakukan sampai jumlah responden yang ditetapkan tercapai atau tepenuhi. (Suryanto,,2011).

\section{Alat Pengumpulan Data}

ata yang digunakan dalam penelitian ini adalah data primer dan data sekunder. Data primer diperoleh dari wawancara dengan menggunakan kuesioner bentuk ceklist pada responden dan data sekunder diperoleh dari telaah dokumen yang berasal dari catatan medis (medical record).

\section{HASIL PENELITIAN}

A. Analisa univariat

\section{Karakteristik Responden}

\section{a) Umur}

Tabel 4.1

Karakteristik responden berdasarkan Umur pasien katarak di Poli Mata RSUD Bangkinang

\begin{tabular}{cccc}
\hline $\begin{array}{c}\text { N } \\
\text { o }\end{array}$ & $\begin{array}{c}\text { Umur } \\
\text { Responde } \\
\text { n }\end{array}$ & $\begin{array}{c}\text { Frekuen } \\
\text { si (n) }\end{array}$ & $\begin{array}{c}\text { Persentas } \\
\mathbf{e}(\boldsymbol{\%})\end{array}$ \\
\hline 1. & $\begin{array}{c}45-64 \\
\text { tahun }\end{array}$ & 7 & 23.3 \\
2. & $\begin{array}{c}65-84 \\
\text { tahun }\end{array}$ & 15 & 50.0 \\
3 & $\begin{array}{c}85-95 \\
\text { tahun }\end{array}$ & 8 & 26.7 \\
\hline & Total & 30 & 100.0 \\
\hline
\end{tabular}

Dari tabel 4.1 di atas dapat dilihat bahwa sebagian besar pasien katarak yang berumur65 84 tahun yaitu sebanyak 15 orang $(50,0 \%)$.

b) Jenis Kelamin

Tabel 4.2

Karakteristik responden berdasarkan Jenis Kelamin pasien katarak di Poli Mata RSUD Bangkinang

\begin{tabular}{|c|c|c|c|}
\hline $\begin{array}{l}\mathbf{N} \\
\mathbf{0}\end{array}$ & $\begin{array}{c}\text { Jenis } \\
\text { Kelamin }\end{array}$ & $\begin{array}{c}\text { Frekuen } \\
\text { si (n) }\end{array}$ & $\begin{array}{c}\text { Persenta } \\
\text { se }(\%)\end{array}$ \\
\hline 1. & $\begin{array}{c}\text { Laki- } \\
\text { laki }\end{array}$ & 19 & 63.3 \\
\hline 2. & $\begin{array}{c}\text { Perempu } \\
\text { an }\end{array}$ & 11 & 36.7 \\
\hline & Total & 30 & 100 \\
\hline & $\begin{array}{r}\text { ari tab } \\
\text { bahw } \\
\text { katara }\end{array}$ & $\begin{array}{l}4.2 \mathrm{di} \\
\text { sebag }\end{array}$ & $\begin{array}{l}\text { as dapat } \\
\text { besar } \\
\text { kelamin }\end{array}$ \\
\hline
\end{tabular}


laki-laki yaitu sebanyak 19 orang $(63,3 \%)$.

c) Pekerjaan

Tabel 4.3

Karakteristik responden berdasarkan Pekerjaan pasien katarak di Poli Mata RSUD Bangkinang

\begin{tabular}{|c|c|c|c|}
\hline $\begin{array}{l}\mathbf{N} \\
\mathbf{0}\end{array}$ & Pekerjaan & $\begin{array}{c}\text { Frekuen } \\
\text { si (n) }\end{array}$ & $\begin{array}{l}\text { Persenta } \\
\text { se (\%) }\end{array}$ \\
\hline 1. & Tani & 14 & 46.7 \\
\hline 2. & Nelayan & 8 & 26.7 \\
\hline 3 & $\begin{array}{l}\text { PNS / } \\
\text { Swasta }\end{array}$ & 3 & 10.0 \\
\hline 4 & $\begin{array}{c}\text { Wiraswas } \\
\text { ta }\end{array}$ & 5 & 16.7 \\
\hline & Total & 30 & 00.0 \\
\hline
\end{tabular}

Dari tabel 4.3 di atas dapat dilihat bahwa sebagian besar pasien katarak mempunyai pekerjaan tani yaitu sebanyak 14 orang $(46,7 \%)$.

2. Kejadian Katarak Senilis

Tabel 4.4

Distribusi frekuensi responden berdasarkan kejadian katarak senilis di Poli Mata RSUD Bangkinang

\begin{tabular}{cccc}
\hline No & $\begin{array}{c}\text { Katarak } \\
\text { Senilis }\end{array}$ & $\begin{array}{c}\text { Frekuensi } \\
(\mathbf{n})\end{array}$ & $\begin{array}{c}\text { Persentase } \\
(\boldsymbol{\%})\end{array}$ \\
\hline 1. & Menderita & $\mathbf{2 2}$ & $\mathbf{7 3 , 3}$ \\
2. & $\begin{array}{c}\text { Tidak } \\
\text { menderita }\end{array}$ & 8 & 26,7 \\
& & \\
\hline & Jumlah & $\mathbf{3 0}$ & $\mathbf{1 0 0}$ \\
\hline
\end{tabular}

Dari tabel 4.4 di atas dapat dilihat bahwa sebagian besar pasien menderita katarak senilis yaitu sebanyak 22 orang (73,3\%). Sebanyak 8 $(26,7 \%)$ menderita Katarak Komplikata akibat penyakit lain, operasi mata sebelumnya dan traumatik.

3. Diabetes Melitus

Tabel 4.5

Distribusi frekuensi responden berdasarkan kejadian diabetes melitus di Poli Mata RSUD Bangkinang

\begin{tabular}{cccc}
\hline No & $\begin{array}{c}\text { Diabetes } \\
\text { Melitus }\end{array}$ & $\begin{array}{c}\text { Frekuensi } \\
(\mathbf{n})\end{array}$ & $\begin{array}{c}\text { Persentase } \\
(\mathbf{\%})\end{array}$ \\
\hline 1. & Berisiko & $\mathbf{2 0}$ & $\mathbf{6 6 , 7}$ \\
2. & Tidak & 10 & 33,3 \\
& Berisiko & & \\
\hline & Jumlah & $\mathbf{3 0}$ & $\mathbf{1 0 0}$ \\
\hline
\end{tabular}

Dari tabel 4.5 di atas dapat dilihat bahwa sebagian besar pasien mengalami riwayat diabetes melitus yaitu sebanyak 20 orang $(66,7 \%)$.

4. Riwayat Keluarga dengan Katarak Tabel 4.6

Distribusi frekuensi responden berdasarkan riwayat keluarga dengan katarak di Poli Mata RSUD Bangkinang

\begin{tabular}{lccc}
\hline No & $\begin{array}{c}\text { Riwayat } \\
\text { Keluarga } \\
\text { Dengan }\end{array}$ & $\begin{array}{c}\text { Frekuensi } \\
(\mathbf{n})\end{array}$ & $\begin{array}{c}\text { Persentase } \\
(\boldsymbol{\%})\end{array}$ \\
& Katarak & & \\
\hline 1. & Berisiko & $\mathbf{1 7}$ & $\mathbf{5 6 , 7}$ \\
2. & Tidak & 13 & 43,3 \\
& Berisiko & & \\
\hline & Jumlah & $\mathbf{3 0}$ & $\mathbf{1 0 0}$ \\
\hline
\end{tabular}

Dari tabel 4.6 di atas dapat dilihat bahwa sebagian besar pasien memiliki riwayat keluarga dengan katarak yaitu sebanyak 17 orang $(56,7 \%)$.

\section{Pemakaian Steroid yang Lama}

Tabel 4.7

Distribusi frekuensi responden berdasarkan pemakaian steroid yang lama di Poli Mata RSUD Bangkinang

\begin{tabular}{lccc}
\hline No & $\begin{array}{c}\text { Pemakaian } \\
\text { Steroid yang } \\
\text { Lama }\end{array}$ & $\begin{array}{c}\text { Frekuensi } \\
\text { (n) }\end{array}$ & $\mathbf{3 6 , 7}$ \\
\hline 1. & Berisiko & $\mathbf{1 1}$ & $\mathbf{3 6 , 7}$ \\
2. & Tidak Berisiko & 19 & 63,3 \\
\hline & Jumlah & $\mathbf{3 0}$ & $\mathbf{1 0 0}$ \\
\hline
\end{tabular}

Dari tabel $4.7 \mathrm{di}$ atas dapat dilihat bahwa sebagian besar pasien tidak memakai obat steroid yang lama yaitu sebanyak 19 orang $(63,3 \%)$.

6. Merokok

Tabel 4.8

Distribusi frekuensi responden berdasarkan perilaku merokok di Poli Mata RSUD Bangkinang

\begin{tabular}{cccc}
\hline No & Merokok & $\begin{array}{c}\text { Frekuensi } \\
\text { (n) }\end{array}$ & $\mathbf{3 6 , 7}$ \\
\hline 1. & Berisiko & $\mathbf{2 1}$ & $\mathbf{7 0 , 0}$ \\
2. & Tidak & 9 & 30,0 \\
& Berisiko & &
\end{tabular}




\begin{tabular}{lll}
\hline Jumlah & 30 & 100 \\
\hline
\end{tabular}

Dari tabel 4.8 di atas dapat dilihat bahwa sebagian besar pasien merokok yaitu sebanyak 21 orang $(70,0 \%)$.

\section{Terpajan Sinar Ultraviolet}

Tabel 4.9

Distribusi frekuensi responden berdasarkan terpajan sinar ultraviolet di Poli Mata RSUD Bangkinang

\begin{tabular}{cccc}
\hline No & $\begin{array}{c}\text { Terpajan sinar } \\
\text { ultraviolet }\end{array}$ & $\begin{array}{c}\text { Frekuensi } \\
(\mathbf{n})\end{array}$ & $\mathbf{3 6 , 7}$ \\
\hline $\mathbf{1 .}$ & Berisiko & $\mathbf{2 3}$ & $\mathbf{7 6 , 7}$ \\
2. & Tidak Berisiko & 7 & 23,3 \\
\hline & Jumlah & $\mathbf{3 0}$ & $\mathbf{1 0 0}$ \\
\hline
\end{tabular}

Dari tabel 4.9 di atas dapat dilihat bahwa sebagian besar pasien terpajan sinar ultraviolet yaitu sebanyak 23 orang $(76,7 \%)$.

\section{B. Analisa Bivariat}

Analisa bivariat ini memberikan analisis fakor-fakor yang berhubungan dengan kejadian katarak senilis di poli mata RSUD Bangkinang. Analisis bivariat ini menggunakan uji Chi-Square sehingga dapat dilihat ada hubungan antara kedua variabel tersebut. Untuk hasil uji Chi-Square maka didapatkan seperti tabel berikut ini.

1. Hubungan Penyakit Diabetes Melitus dengan Kejadian Katarak Senilis di Poli Mata RSUD Bangkinangbahwa dari 20 responden yang menderita penyakit diabetes melitus, terdapat 2 responden (10\%) yang tidak menderita katarak senilis. Sedangkan dari 10 responden yang tidak menderita penyakit diabetes melitus, terdapat 4 responden (40\%) yang menderita katarak senilis.Berdasarkan uji statistik diperoleh bahwa $\mathrm{p}$ value $=0,007$ ( $\mathrm{p}$ $\leq 0,05$ ), ini berarti ada hubungan penyakit diabetes melitus dengan kejadian katarak senilis di Poli Mata RSUD Bangkinang. Berdasarkan hasil penelitian juga diketahui bahwa nilai Prevalent Odds Rasio $=13,5$, hal ini berarti responden yang menderita penyakit diabetes melitus berpeluang 13,5 kali mengalami katarak senilis.
2. Hubungan Riwayat Keluarga Katarak dengan Kejadian Katarak Senilis di Poli Mata RSUD Bangkinangbahwa dari 17 responden yang mempunyai riwayat keluarga dengan katarak, terdapat 1 responden $(5,9 \%)$ yang tidak menderita katarak senilis. Sedangkan dari 13 responden yang tidak mempunyai riwayat keluarga dengan katarak, terdapat 6 responden $(46,2 \%)$ yang menderita katarak senilis. Berdasarkan uji statistik diperoleh bahwa $\mathrm{p}$ value $=0,009 \quad(\mathrm{p} \leq 0,05)$, ini berarti ada hubungan riwayat keluarga dengan katarak dengan kejadian katarak senilis di Poli Mata RSUD Bangkinang. Berdasarkan hasil penelitian juga diketahui bahwa nilai Prevalent Odds Rasio $=18,6$ hal ini berarti responden yang menderita penyakit diabetes melitus berpeluang 18,6 kali mengalami katarak senilis.

3. Hubungan Pemakaian Steroid Lama dengan Kejadian Katarak Senilis di Poli Mata RSUD Bangkinangbahwa dari 19 responden yang tidak menggunakan obat steroid yang lama, terdapat 13 responden $(64,8 \%)$ menderita katarak senilis.Berdasarkan uji statistik diperoleh bahwa $\mathrm{p}$ value $=0,67(\mathrm{p}$ > $0,05)$, ini berarti tidak ada hubungan pemakaian steroid lama dengan kejadian katarak senilis di Poli Mata RSUD Bangkinang. Berdasarkan hasil penelitian juga diketahui bahwa nilai Prevalent Odds Rasio $=$ 2,0 hal ini berarti responden yang tidak menggunakan obat steroid lama berpeluang 2 kali mengalami katarak senilis.

4. Hubungan Merokok dengan Kejadian Katarak Senilis di Poli Mata RSUDBangkinangbahwa dari 21 responden yang merokok, terdapat 3 responden $(14,3 \%)$ yang tidak menderita katarak senilis. Sedangkan dari 9 responden yang tidak merokok, terdapat 4 responden $(44,4 \%)$ yang menderita katarak senilis. Berdasarkan uji statistik diperoleh bahwa $\mathrm{p}$ value $=0,03(\mathrm{p}$ $\leq 0,05$ ), ini berarti ada hubungan merokok dengan kejadian katarak senilis di Poli Mata RSUD Bangkinang. Berdasarkan hasil penelitian juga diketahui bahwa nilai Prevalent Odds Rasio $=7,5$ hal ini berarti responden yang merokok berpeluang 7,5 kali mengalami katarak senilis. 
5. Hubungan Terpajan Banyak Sinar Ultraviolet dengan Kejadian Katarak Senilis di Poli Mata RSUD Bangkinang bahwa dari 23 responden yang terpajan banyak sinar ulraviolet, terdapat 2 responden $(8,7 \%)$ tidak menderita katarak senilis. Sedangkan dari 7 responden yang tidak terpajan banyak sinar ulraviolet, terdapat 1 responden $(14,3 \%)$ menderita katarak senilis. Berdasarkan uji statistik diperoleh bahwa $\mathrm{p}$ value $=0,000(\mathrm{p} \leq$ $0,05)$, ini berarti ada hubungan terpajan sinar ultraviolet yang lama dengan kejadian katarak senilis di Poli Mata RSUD Bangkinang. Berdasarkan hasil penelitian juga diketahui bahwa nilai Prevalent Odds Rasio $=63$ hal ini berarti responden yang terpajan sinar ultraviolet yang lama berpeluang 63 kali mengalami katarak senilis.

\section{PEMBAHASAN}

A. Hasil analisis Bivariat

1. Hubungan Penyakit Diabetes Melitus dengan Kejadian Katarak Senilis di Poli Mata RSUD Bangkinang

Setelah dilakukan uji Statistik dengan menggunakan uji chi-squere, maka didapatkan hasil ada hubungan penyakit diabetes melitus dengan kejadian katarak senilis di Poli Mata RSUD Bangkinang dengan $\mathrm{p}$ value 0,007 ( $\leq$ 0,05). Berdasarkan hasil penelitianjuga diketahui bahwa nilai Prevalent Odds Rasio = 13,5, hal ini berarti responden yang menderita penyakit diabetes melitus berpeluang 13,5 kali mengalami katarak senilis.

Menurut asumsi peneliti responden yang menderita diabetes melitus terjadi karena mengalami diabetes melitus yang tidak terkontrol. Akibat peningkatan dari gula darah dapat menyebabkan penumpukan zat-zat metabolik gula oleh sel-sel lensa mata, tekanan osmosis intraseluler meningkat dan terbentuklah katarak. Sedangkan responden yang menderita diabetes melitus tetapi tidak mengalami katarak disebabkan karena selalu mengotrol dan mempertahankan kadar gula darah dalam batas normal dan selalu mencheck-up kesehatan mata secara rutin, serta menderita diabetes melitus tapi baru beberapa bulan terakhir mengalami peningkatan gula darah (hasil wawancara).
Menurut Yugiantoro (2008) proses terjadinya katarak pada diabetes melitus karena penumpukan glukosa pada mata. Dalam keadaan normal, penumpukan zat-zat sisa tidak terjadi, bila kadar gula darah meningkat, maka perubahan glukosa oleh aldose reduktase menjadi serbitol meningkat. Selain itu perubahan serbitol menjadi fruktose relatif lambat dan tidak seimbang sehingga kadar serbitol dalam lensa mata meningkat, sorbitol menaikkan tekanan osmose intraseluler dengan akibat meningkatnya water uptake dan selanjutnya secara langsung maupun tidak langsung terbentuklah katarak. Pengaruh klinis lama mengakibatkan terjadinya katarak lebih dini pada pasien dibandingkan dengan pasien non diabetes.

Menurut Budiman (2013) Diabetes melitus merupakan kelainan metabolik yang ditandai dengan hiperglikemia yang terkait dengan sekresi insulin, defek aksi insulin atau keduanya. Kondisi hiperglikemia kronik ini berhubungan dengan sekuele jangka panjang yang signifikan, yaitu kerusakan, disfungsi dan kegagalan pada beberapa organ, khususnya ginjal, mata, saraf, jantung dan pembuluh darah. Pada mata dapat menyebabkan edema lensa akibat sorbitol (alkohol gula).

Hasil penelitian ini sesuai dengan penelitian yang dilakukan oleh Burhan (2012) dengan judul faktor-faktor yang berhubungan dengan katarak senilis di Poliklinik Mata Budi Asih Depok, yang didapatkan bahwa ada hubungan penyakit diabetes melitus dengan terjadinya katarak senilis dengan $p$ value 0,003 .

2.Hubungan Riwayat Keluarga Katarak dengan Kejadian Katarak Senilis di Poli Mata RSUD Bangkinang

Setelah dilakukan uji Statistik dengan menggunakan uji chi-squere, maka didapatkan hasil ada hubungan riwayat keluarga dengan katarak dengan kejadian katarak senilis di Poli Mata RSUD Bangkinang dengan $p$ value 0,009 $(\leq 0,05)$. Berdasarkan hasil penelitian juga diketahui bahwa nilai Prevalent Odds Rasio = 18,6 hal ini berarti responden yang menderita penyakit diabetes melitus berpeluang 18,6 kali mengalami katarak senilis.

Menurut asumsi peneliti riwayat keluarga dengan katarak dapat berpengaruh terhadap 
penerusan gen kepada keturunan. Beberapa gen kristalin diekspresikan pada awal embriogenesis, dan mutasi pada gen ini dapat menyebabkan perubahan pada protein yang berperan terhadap agregasi protein hingga mengakibatkan terjadinya katarak. Sedangkan responden yang memiliki riwayat keluarga dengan katarak tetapi tidak menderita katarak karena bisa jadi responden ini secara kebetulan tidak mendapat penerusan gen katarak dan terhindar atau terminimalisir dari faktor-faktor lain yang dapat berpengaruh terhadap katarak senilis seperti kebiasaan merokok dan terpajan sinar ultraviolet yang lama serta karakteristik responden (usia, jenis kelamin, pekerjaan).

Menurut Nengsih (2013), katarak berhubungan dengan kelainan genetik,Katarak yang disebabkan karena riwayat keturunan dikaitkan juga dengan pengaruh lingkungan luar yang dapat menyebabkan perubahan genetik dalam tubuh seseorang. Gen ini menyebabkan perubahan pada protein yang berperan terhadap agregasi protein hingga mengakibatkan terjadinya katarak.

Menurut Budiman, dkk (2013) riwayat keluarga dengan katarak dapat berpengaruh terhadap penerusan gen kepada keturunan. Beberapa gen kristalin diekspresikan pada awal embriogenesis, dan mutasi pada gen ini dapat menyebabkan perubahan pada protein yang berperan terhadap agregasi protein hingga mengakibatkan terjadinya katarak senilis.

Hasil penelitian ini sesuai dengan penelitian yang dilakukan oleh Samsudin (2013) dengan judul pengaruh riwayat keturunan dengan terjadinya katarak senilis pada pasien yang berobat pada balai kesehatan masyarakat Nusa Tenggara Barat, hasil penelitian dipeoleh $\mathrm{p}$ value 0,004 hal ini berarti ada hubungan riwayat keturunan dengan terjadinya katarak senilis pada pasien yang berobat pada balai kesehatan masyarakat Nusa Tenggara Barat.

3.Hubungan Pemakaian Steroid Lama dengan Kejadian Katarak Senilis di Poli Mata RSUD Bangkinang

Setelah dilakukan uji statistik dengan menggunakan uji chi-squere, maka didapatkan hasil tidak ada hubungan pemakaian steroid lama dengan kejadian katarak senilis di Poli
Mata RSUD Bangkinang dengan $\mathrm{p}$ value 0,67 $(\leq 0,05)$. Berdasarkan hasil penelitian juga diketahui bahwa nilai Prevalent Odds Rasio = 2,0 hal ini berarti responden yang tidak menggunakan obat steroid lama berpeluang 2 kali mengalami katarak senilis.

Menurut asumsi peneliti, penggunaan jangka panjang ( $\geq 40$ hari) steroid atau dosis tinggi steroid dapat menginduksi protein (miosilin) yang berada di daerah trabekulum sehingga menyebabkan terjadinya edema di daerah tersebut. Edema tersebut yang menginduksi terjadinya glaukoma sudut terbuka. Berdasarkan hasil penelitian tidak ada responden yang menggunakan obat steroid yang lama (> 40 hari), mereka hanya menggunakan obat steroid dalam jangka waktu 2-3 minggu. Jika responden mengalami katarak senilis, dari hasil wawancara bahwa hal ini disebabkan karena responden mempunyai beberapa faktor lain sebagai predisposisi terhadap terjadinya katarak senilis seperti diabetes melitus, merokok dan terpajan sinar ultraviolet serta katarak yang didapat (genetik) serta faktor usia (65 - 85 tahun) dan pekerjaan responden sebagai petani dan nelayan.

Menurut FKUI (2012) Penggunaan jangka panjang (> 40 hari) steroid atau dosis tinggi steroid dapat menyebabkan dua masalah mata yaitu katarak dan glaukoma.Jenis katarak yang bisa terjadi yaitu katarak kortikal posterior. Biasanya pada penggunaan kortikosteroid dalam jangka waktu yang lama bisa menyebabkan katarak posterior sub kapsular.

Hasil penelitian ini sesuai dengan penelitian yang dilakuka oleh Pujiyanto (2011) menerangkan bahwa tingkat pendapatan rendah memberikan pengaruh yang bermakna, dengan nilai $\mathrm{p}=0,03$ dengan tingkat risiko 2 kali lipat dibandigkan dengan subjek yang berpenghasilan tinggi. Responden yang mempunyai pendapatan rendah berisiko 18 kali untuk terjadi katarak dibandingkan dengan responden berpendapatan tinggi.

4.Hubungan Merokok dengan Kejadian

Katarak Senilis di Poli Mata RSUD Bangkinang

Setelah dilakukan uji Statistik dengan menggunakan uji chi-squere, maka didapatkan hasil ada hubungan merokok dengan kejadian 
katarak senilis di Poli Mata RSUD Bangkinang dengan $p$ value $0,03(\leq 0,05)$. Berdasarkan hasil penelitian juga diketahui bahwa nilai Prevalent Odds Rasio $=7,5$ hal ini berarti responden yang merokok berpeluang 7,5 kali mengalami katarak senilis.

Menurut asumsi peneliti bahwa merokok dapat meningkatkan risiko terjadinya katarak. Merokok dapat menginduksi stress oksidatif dan dihubungkan dengan penurunan kadar antioksidan, askorbat dan karotenoid yang secara terus-menerus akan mempercepat kerusakan protein lensa. Sedangkan responden yang merokok tetapi tidak terkena katarak, dari hasil wawancara bahwa penyebabnya karena usia responden ( $<50$ tahun) dan faktor-faktor lainnya seperti pekerjaan responden sebagai pegawai PNS/Swasta.

Menurut Asman (2011) merokok merupakan salah satu kebiasaan yang akan memberikan banyak dampak negatif terhadap kesehatan, asap rokok yang mengandung radikal bebas dapat menyebabkan perubahan molekul protein sehingga dapat menimbulkan katarak.

Menurut Khurana (2007) merokok menyebabkan penumpukan molekul berpigmen 3-hydroxikhynurinine dan chromophores yang menyebabkan terjadinya penguningan warna lensa.Sianat dalam rokok juga menyebabkan terjadinya karbamilasi dan denaturasi protein.(Khurana AK, 2007).

Hasil penelitian ini sesuai dengan penelitian yang dilakukan oleh Panjaitan (2013). Pada penelitian dengan menggunakan kasus-kontrol, di mana kasus sebanyak 54 orang dan kontrol 35 orang, hasil uji multivariat $(\mathrm{OR}=2,287)$ menunjukkan hubungan merokok dapat meningkatkan kejadian katarak 2 kali dibandingkan dengan yang tidak merokok.

5. Hubungan Terpajan Banyak Sinar Ultraviolet dengan Kejadian Katarak Senilis di Poli Mata RSUD Bangkinang

Setelah dilakukan uji Statistik dengan menggunakan uji chi-squere, maka didapatkan hasil ada hubungan terpajan sinar ultraviolet yang lama dengan kejadian katarak senilis di Poli Mata RSUD Bangkinang dengan $\mathrm{p}$ value $0,000(\leq 0,05)$. Berdasarkan hasil penelitian juga diketahui bahwa nilai Prevalent Odds Rasio $=63$ hal ini berarti responden yang terpajan sinar ultraviolet yang lama berpeluang 63 kali mengalami katarak senilis

Menurut asumsi peneliti, dari hasil wawancara didapatkan sebagian besar responden adalah petani dan nelayan sehingga paparan sinar ultraviolet, yang berasal dari sinar matahari (lebih dari 4 jam) akan diserap oleh protein lensa terutama reaksi asam amino yang berubah menjadi molekul bersifat radikal bebas yang akan menimbulkan kekeruhan lensa atau yang disebut katarak. Sedangkan orang yang terpajan sinar utraviolet tetapi tidak terkena katarak disebabkan karena usia yang kurang dari 50 tahun dan responden menggunakan alat pelindung mata (kaca mata buram/hitam) atau topi besar saat bekerja di bawah terik matahari sehingga risiko katarak tidak terjadi.

Menurut Tamhuzi (2006) Masuknya radiasi sinar ultraviolet secara langsung ke dalam mata dapat dikurangi dengan menggunakan alat pelindung diri seperti topi saat bekerja di luar gedung. Bahaya akan sinar ultaviolet ini belum banyak diketahui oleh responden, sehingga perlu diadakan penyuluhan atau promosi kesehatan untuk menggunakan alat pelindung diri saat berada di luar gedung.

Berdasarkan hasil Riakesdas (2007) beberapa pekerjaan yang cukup berisiko untuk terjadinya katarak di antaranya adalah petani, buruh dan nelayan. Hal ini sejalan dengan pekerjaan responden pada saat penelitian, responden kebanyakan memiliki pekerjaan sabagai petani, buruh, dan pedagang keliling, jenis pekerjaan yang berada di luar gedung dikaitkan dengan paparan sinar ultraviolet langsung. Apabila dalam waktu yang lama bekerja di luar gedung dan terpapar sinar matahari, akan sangat berbahaya karena radiasi sinar ultraviolet dari matahari akan diserap oleh lensa, sehingga akan menyebabkan lensa menjadi keruh.

Menurut Sinha, dkk (2009), pekerjaan yang berada di luar ruangan (lapangan) tingkat kematangan kataraknya terlihat meningkat. Responden pada kelompok pekerja lapangan dengan tingkat kematangan katarak lebih tinggi (62\%) dibanding dengan responden pada kelompok pekerja di dalam ruangan (41.9\%). 
Penelitian ini didukung dengan hasil penelitian Sinha, dkk (2009) yang menyebutkan ada pengaruh yang bermakna antara tingkat kematangan katarak senilis dengan pekerjaan. Dalam penelitiannya, Sinha menyebutkan bahwa, pekerjaan responden yang berada di luar gedung memiliki tingkat kematangan katarak sekitar $62 \%$ dibanding dengan responden pada kelompok pekerja di dalam gedung yaitu sekitar $41.9 \%$.

\section{PENUTUP}

Pada bab ini akan diuraikan simpulan dan saran yang diperoleh berdasarkan penjelasan bab sebelumnya serta saran yang diberikan berupa masukan yang bersifat operasional dan terkait hasil penelitian.

A.Simpulan

Dari hasil penelitian dan pembahasan pada bab-bab sebelumnya, maka dapat ditarik kesimpulan pada penelitian ini yang berjudul "fakor-fakor yang berhubungan dengan terjadinya katarak senilis di poli mata RSUD Bangkinang, sebagai berikut:

1.Terdapat hubungan bermakna antara diabetes melitus dengan kejadian katarak senilis di poli mata RSUD Bangkinang.

2.Terdapat hubungan bermakna antara riwayat keluarga dengan katarak dengan kejadian katarak senilis di poli mata RSUD Bangkinang.

3.Tidak terdapat hubungan bermakna antara menggunakan steroid yang lama dengan kejadian katarak senilis di poli mata RSUD Bangkinang.

4.Terdapat hubungan bermakna antara merokok dengan kejadian katarak senilis di poli mata RSUD Bangkinang.

5.Terdapat hubungan bermakna antara terpajan sinar ultraviolet yang lama dengan kejadian katarak senilis di poli mata RSUD Bangkinang.

\section{B.Saran}

\section{Bagi responden}

Katarak hanya dapat diatasi melalui prosedur operasi. Akan tetapi jika gejala katarak tidak mengganggu, tindakan operasi tidak diperlukan. Kadang kala cukup dengan mengganti kacamata. Hingga saat ini belum ada obat-obatan, makanan, atau kegiatan olah raga yang dapat menghindari atau menyembuhkan seseorang dari gangguan katarak. Akan tetapi melindungi mata terhadap sinar matahari yang berlebihan dapat memperlambat terjadinya gangguan katarak. Kacamata gelap atau kacamata reguler yang dapat menghalangi sinar ultraviolet (UV) sebaiknya digunakan ketika berada diruang terbuka pada siang hari.

Khususnya di kelompok berisiko tinggi seperti penderita merokok dan diabetes melitus, disarankan untuk berhenti merokok atau tidak merokok serta mencari konsultasi medis jika penglihatan 'halo' yang terjadi disekitar lampu jalan di malam hari, terutama jika fenomena ini tampak hanya dengan satu mata.

2.Bagi Institusi Pelayanan Kesehatan

Agar membuat program penanggulangan untuk penyakit katarak seperti pemeriksaan mata berkala dan operasi katarak gratis Memberikan informasi berupa poster atau leaflet kepada masyarakat tentang penyebab, gejala dan tanda-tanda terjadinya katarak.

\section{Bagi Institusi Pendidikan (STIKes Tuanku Tambusai Riau) \\ Hasil penelitian ini diharapkan dapat dijadikan data dasar bagi peneliti selanjutnya dibidang kesehatan, khususnya tentang penyakit katarak dan juga diharapkan dapat dipergunakan sebagai bahan kepustakaan. \\ 4.Bagi peneliti selanjutnya \\ Diharapkan bagi peneliti selanjutnya agar dapat menambah variabel lain dalam penelitian sehingga dapat diketahui faktor lain yang menyebabkan terjadinya katarak senilis.}




\section{DAFTARPUSTAKA}

Alimul Hidayat, A. Aziz. 2008. Metode Penelitian Keperawatan dan Teknik Analisa Data. Jakarta: Salemba Medika

Amanda Nazira, 2015. Dkk. Jurnal, Katarak Senilis, Risiko bagi orang yang berusia lanjut. http://www.docfoc.com/jurnal-eptmkatarak. Akses 5 April 2016

Arikunto. 2010. Prosedur Penelitian Suatu Pendekatan Praktis. Jakarta: Salemba Medika

Arimbi, A. T., 2011. Faktor-faktor yang Berhubungan dengan Katarak Degeneratif di RSUD Budhi Asih. p. Depok: Universitas Airlangga

Budiman, 2013. Teknik, Komplikasi dan Penatalaksanaan Bedah Katarak. Perpustakaan Nasional RI

Budiman, Andrew, M.H.K., Novita, S., 2013. Pearl and PitFalls to Improve Cataract Surgery Skills. Perpustakaan Nasional RI

Ilyas S., 2014. Ilmu Penyakit Mata. 5 ed. Jakarta: Balai Penerbit Fakultas Kedokteran Universitas Indonesia

Klinik Mata Nusantara. Teknik Operasi Katarak.http://www.klinikmatautama .com. Akses 30 Maret 2016

Machfoedz, Ircham. 2009. Metodologi Penelitian Bidang Kesehatan, Keperawatan, Kebidanan, Kedokteran. Yogyakarta: Penerbit Fitramaya

News Medical, 2013. Cigarette smoking may increase risk of age-related cataract. $\quad$ http://www.newsmedical.net/news/20121013/Cigare tte-smok ing-may-increase-risk-ofage-related-cataract.aspx. Akses 7 April 2016

Study Cataract Surgery. $\quad$ http://www.newsmedical.net/news/20130905/studycataract-surgery-aspx. Akses 7 Apr 2016

Notoatmodjo, Soekidjo. 2010. Ilmu Perilaku Kesehatan. Jakarta: Rineka Cipta

$\begin{array}{ll} & \\ \text { Penelitian } & \text { Metodologi } \\ \text { Rineka Cipta } & \text { Jakarta: }\end{array}$

Nursalam. 2009. Konsep dan Penerapan Metodologi Penelitian Ilmu Keperawatan Pedoman Skripsi, Tesis, dan Instrumen Penelitian Keperawatan. Jakarta: Salemba Medika
PERDAMI, 2013. Tjahjono D. G., Panduan Manajemen Klinis Perdami. PP Perdami. Jakarta

Putrilestari, Ardian. 2013. Artikel Katarak.https://keperawatanb.wordpr ess.com/. Akses 5 September 2016

Pujiyanto, T. I., 2004. Faktor-faktor Resiko yang Berpengaruh terhadap Kejadian Katarak Senilis. In: Semarang: Universitas Diponegoro

Riskesdas. 2013. Laporan Nasional Riset Kesehatan Dasar.Situasi gangguan penglihatan dan kebutaan. Jakarta: Badan Penelitian dan Pengembangan 
kesehatan Departermen Kesehatan Republik Indonesia

Riskesdas, 2013. Laporan hasil Riskesdas Prov. Riau 2013. http://www.pusat2.litbang.depkes.go. id/pusat2_v1/wpcontent/uploads/2015/02/PokokPokok-Hasil-Riskesdas-Prov-Riau.pdf. Akses 3 April 2016

RSCM Kirana, 2015. Penggunaan Kortikosteroid dan Obat Imunosupresif.http://mata-fkuirscm.org/panduan-pasien/edukasipasien/penggunaan-kortikosteroid/. Akses 5 April 2016

Rumah Sakit Umum Daerah Bangkinang. SIMRS 2016. Data Kunjungan Poli Mata RSUD Bangkinang

Sastroasmoro, Sudigdo, dkk. 2011. DasarDasar Metodologi Penelitian Klinis Edisi Ke 4. Jakarta: CV. Sagung Seto

Setiadi. 2007. Konsep \& Penulisan Riset Keperawatan. Yogyakarta: Graha Ilmu

Sinha $\mathrm{R}$ et al, Etiopathogenesis of Cataract: Journal Review. Indian Journal of Ophtalmology Vol. 57 No.3; May- June 2009.p248-249

Suriasumantri, Jujun S. 2009. Filsafat Ilmu: Sebuah Pengantar Populer. Jakarta: Penebar Swadaya

Suryanto, 2011. Metodeologi dan Aplikasi Penelitian Keperawatan.Yogyakarta: Nuha Medika.

Ulandari, Ni Nyoman S. T., 2014. Pengaruh pekerjaan dan pendidikan terhadap terjadinya katarak di balai kesehatan mata masyarakat Nusa Tenggara Barat. Denpasar: Universitas Udayana

World

Health

Organization2013.Blindness: Vision 2020- the global initiative for the elimination of avoidable blindness. Available at http://www.who.int/mediacentre/fact sheet/fs213/en/. Akses 5 April 2016 